\title{
A Study on Impact of Socio-Economic Profile on Investment Pattern of Salaried \& Business People in Coimbatore City
}

\author{
Dr.V.Ramanujam ${ }^{1}$ K. Chitra Devi ${ }^{2}$ \\ ${ }^{1}$ Assistant Professor, ${ }^{2}$ M.Phil Research scholar \\ Bharathiar School of Management \& Entrepreneur Development, \\ Bharathiar University, Coimbatore
}

\begin{abstract}
In recent times, the investment companies have emerged as the most dynamic segment in the Indian financial system. Reforms in the Indian economic system and the opening up of the economy have been the reasons for the tremendous growth in the Indian capital market. This study analyzes the impact of socio economic variables on the attitude of investors towards investments. Apart from this, it also focuses on the benefits delivered by savings to investors. To achieve, 100 respondents of Coimbatore city, having different socio economic profiles were surveyed. The results also highlight that certain factors like education level, awareness about the financial system, age of invertors etc make significant impact while deciding on the investment patterns for investment.

Further, it is observed that the level of income also influences the investment decisions. Higher income group shows relatively high preference towards investment in share market, conversely lower and average income group shows keen preference towards insurance and banks as the most preferred investment avenues.
\end{abstract}

Keywords: Investors, Investment Pattern and Investment Attitude

\section{INTRODUCTION}

Until the decade of the 90's, most of the middle class Indians were paying little attention to managing personal finance during their working life span and only at the time of retirement they would consult their well wishers or advisors about some deposit schemes with banks or post office or companies which would ensure them regular monthly or quarterly returns. A very small percentage of the rich and daring or adventurous Indians would experiment in stock markets or UTI schemes with the advent of the new millennium, needs have multiplied and changed and so have the solutions. The importance of correct advice at the right time is being appreciated and an average Indian is trying to remain a best of the development in finance markets so as to manage his "Personal Finance" efficiently.

Weber (1999) makes the following observation, "Behavioral finance closely combines individual behavior and market phenomena and uses the knowledge taken from both psychological field and financial theory".

Behavioral finance seeks to identify market conditions in which investors are likely to overreact or under react to new information. Behavioral finance tries to understand how people forget fundamentals and make investments based on emotions.

Investments have become a basic necessity for everyone. In our country there is a rapid growth in investment. More number of investors is investing their funds in different types of investment opportunities. Investing wisely is a function if investors' specific needs and goals. Each investor has different objectives that need to be met depending on age, income and attitude towards risk. Investors have to work out with their investment profile to determine which investments are right for them and should consider important factors such as personal status, plans and constraints. Now a day the salaried and Business 
investors select almost all kinds of investment avenues for their investment. They all improve the economic development of a country.

\subsection{Statement of the Problem}

Income pattern of people differs from salaried person and business person. The salaried employees receive house rent allowance whereas some others prefer to have rent free accommodation. Some may receive conveyance allowance whereas some others may prefer to use the conveyance provided by their employers. Some may receive fees, bonus, commission, etc., whereas some others may not have the opportunity to receive these types of incomes. Also employees may earn income from various other sources. Therefore, the income pattern of employees differs in many aspects. So some employees may adopt tax planning measures to reduce their tax liability.

\subsection{Need for the Study}

The study reveals the relationship between the economics condition of the investor and their preference towards different modes of investment. This study may aware the people about the investor's investment behavior based on their regularity of return.

Day by day there is growing demand for wealth management functions. It includes the understanding of investor's requirements and providing financial plan according to it. Hence it becomes behavior and psychology.

\subsection{Scope of the study}

The researcher would gain more practical knowledge in the field of wealth management service. The result of this research would help the people involved in the wealth management process in advising their salaried and business class investors regarding investments that are most suitable according to their demographics and personality type.

\subsection{Objectives of the Study}

1. To study the impact of socio-economic profile on investment pattern of salaried and business class people.

2. To analyze the investment pattern among the salaried and business class investors.
3. To analyze the investment attitude towards salaried and business class investors.

4. To find the problems facing by the investors.

\subsection{Limitations}

Through the present research paper is aimed to achieve the above-mentioned objective in full earnest and accuracy, there are certain limitations.

1. The time factor was the main limitation for completion of the research, and the study was conducted targeting the investors in Coimbatore city only.

2. The primary data has been collected a structured questionnaire to a sample of 100 investors in Coimbatore city, which may not reflect the opinion of the entire population.

\section{LITERATURE REVIEW}

${ }^{1}$ Tamilkodi, (1983) has stated that small savings schemes have a psychological appeal and it provides an opportunity for ordinary men, women, and even children to park their savings. It reaches a large number of people and covers a wide range of areas. She also suggested that efforts should be taken to simplify the procedure of small savings schemes to suit the needs of illiterate and socially downtrodden people. Further, she suggested an increase in the rate of interest of small savings schemes to meet the challenges of commercial banks.

2Jayaraman, (1987) has stated that instead of issuing special bonds for unearthing black money the Government of India can encourage investment of black money in various small savings schemes. He further stressed the need to draft the assistance of voluntary agencies at the school and college level for further mobilization of savings.

${ }^{3}$ Mukhi, (1989) has revealed that NSC has been one of the most popular tax savings instruments in this country. He has stated that contractor and others who have to provide security while bidding for contracts finds it extremely convenient to buy NSC and pledge these to the appropriate authorities while earning 12 per cent per annum on the pledged securities. He also stated that the major attraction of NSC is its simplicity. Even the 
average investor does not have to scratch his head to understand the scheme.

${ }^{4}$ Somasundaram (1998) has found that bank deposits and chit funds were the best known mode of savings among investors and the least known mode were Unit Trust of India (UTI) schemes and plantation schemes. Attitudes of investors were highly positive and showed their intention to save for better future.

${ }^{5}$ Guiso, Jappelli and Terlizzese (1996), Bajtelsmit and VenDerhei (1997), Powell and Ansic (1997), Jianakoplos and Bernasek (1998), Hariharan, Chapman and Domain (2000), Hartog, Ferrer-ICarbonell and Jonker (2002) concluded that males are more risk tolerant than females.

${ }^{6}$ Rajarajan. V. (2003) studies brought out the existence of strong association between demographic characteristics and the risk bearing capacity of Indian investors, the relationship between age, income and risk bearing capacity of the investors are very high. The salaried members constituted the largest part of all categories.

${ }^{7}$ Sharma. B.C. and Sharma Dinesh's (2004) research paper explores the literature and points out that stock investment activity by retail investors is very low in India. This paper studied about retail investor's investment patterns behavior and attitudes that they hold about stock investing in the context is of small emerging market of Jammu. The result of the study showed that profile of retail investor as young, well informed and also regular traders. However, they hold moderately low belief towards stock market Institution's regulatory capabilities and towards safety of small investor.

${ }^{8}$ Dr.V.L shobhana and J.Jayalakshmi in their study titled 'investor Awareness and Preference. A study" (2005) has examined the level of investor awareness regarding investment options and investment risks. The analysis revealed that investment in real estate/property is preferred by majority of the respondents. The second most preferred investment is bank deposits. Awareness about investment options and risks are high among old aged, highly educated and those who are professionals by occupation. Demographic variables such as age and education do not have significant influence over investor awareness where as difference in occupational status leads to difference in the awareness level of people.

${ }^{9}$ Love D.A (2010) investigated the impact of demographic shocks on optimal decisions about savings, life insurance and most certainly assets allocation and found that marital status transitions could have important effects on optimal household decisions, particularly in the cases of widowhood and divorcee. He also found that children also play a fundamental role in portfolio choice, and the literature on optimal portfolio choice over the life cycle has focused on the roles of housing costs and background risks due to labor income. His empirical evidence shows that divorce and widowhood have particularly strong effects on allocations, and that these effects differ significantly by gender, age and number of children.

${ }^{10}$ Rajarajen Vanjeko (2010) individual investors are the backbone of the capital market. The growth of the capital market during the last few years has substantially increased the investor population in our country. The investment scene has undergone a sea change. This context necessitates an understanding of the characteristics of investors in terms of their investments, strategies, expectations etc. this paper presents some interesting information on this line on the basis of information collected from over thousand individual investors from eleven cities of India. This study suggests the use of these characteristics for a better understanding of individual investors and their financial product needs. It also shows investor's future investment preferences. The study reveals the increasing popularity of equity as an investment option among individual investors.

\section{HYPOTHESIS OF THE STUDY}

The hypothesis of the study can be described here in as under:

- There is no significant association between the occupation of respondents and frequency of making investment.

- There is no significant association between the family annual income of respondents and frequency of making investment. 
- There is no significant association between the individual annual income of respondents and frequency of making investment.

- There is no significant difference between the attitude of government, public and private class of salaried investor towards investments.

- There is no significant difference between the attitude of manufacture, retail and service class of business investor towards investments.

- There is no significant difference between the investment pattern of government, public and private class of salaried investors.

- There is no significant difference between the investment pattern of business, retail and service class of business investors.

\subsection{Methodology}

The present study is an impact of socio -economic profile and investment pattern of salaried and business people in Coimbatore city. The study area is featured by a good number of salaried, professional \& businessmen who have the ability to save \& invest. Besides, the study area is featured with all the facilities that are needed for mobilizing \& transmitting the idle savings. This research study is a descriptive kind of research study. In order to conduct this study, 100 Investors in Coimbatore city have been surveyed and questionnaire is used for data collection. Pilot Study At first a pilot study of 20 respondents was made, and the improvements suggested by the respondents were incorporated in the final questionnaire.

Sources of Data All the data required for this purpose has been obtained mainly from primary sources, secondary sources of data have also been referred.

Data Collection Methods The data collection method used to obtain the desired information from primary sources has been through direct interview and questionnaire has been used as an instrument.

Sampling Plan Target Population or Universe: Investors in Coimbatore City

Sampling Unit: An individual investor in Coimbatore City
Sampling Method: Convenient sampling

Sample Size: 100

Area of Survey: Various localities in Coimbatore City

Statistical Tools and Techniques For measuring various phenomena and analyzing the collected data effectively and efficiently to draw sound conclusions, a number of statistical techniques including ANOVA, Mean, Cross tabulation and chi-square test for the testing of hypotheses have been used.

\subsection{Data Analysis and Interpretation}

Table 1 Showing the Gender of the Respondents

\begin{tabular}{|l|l|l|l|l|}
\hline \multirow{2}{*}{$\begin{array}{l}\text { S. } \\
\text { No }\end{array}$} & Gender & \multicolumn{2}{|l|}{$\begin{array}{l}\text { Number of } \\
\text { Investors }\end{array}$} & \multirow{2}{*}{ Total } \\
\cline { 3 - 4 } & & Salaried & Business & \\
\hline 1 & Male & 31 & 38 & 69 \\
\hline 2 & Female & 19 & 12 & 31 \\
\hline & Total & 50 & 50 & 100 \\
\hline
\end{tabular}

\section{Source: Primary Data}

The Table.1 shows the gender wise classification of the respondents. Out of the total 100 respondents 69 respondents were male and it includes 31 investors from salaried and 38 respondents from business people. Out of the remaining 31 respondents, 19 investors were from salaried and the remaining 12 investors were from business people.

Table 2 Showing the Age of the Respondents

\begin{tabular}{|l|l|l|l|l|}
\hline \multirow{2}{*}{$\begin{array}{l}\text { S. } \\
\text { No }\end{array}$} & $\begin{array}{l}\text { Age } \\
\text { in } \\
\text { years })\end{array}$ & \multicolumn{2}{|l|}{ Number of Investors } & Total \\
\cline { 2 - 4 } & $\begin{array}{l}\text { Salaried } \\
30\end{array}$ & 28 & Business & \\
\hline 2 & $31-40$ & 8 & 11 & 37 \\
\hline 3 & $41-50$ & 5 & 12 & 19 \\
\hline 4 & $51-60$ & 7 & 13 & 20 \\
\hline 5 & $\begin{array}{l}61 \& \& \\
\text { Above }\end{array}$ & 2 & 5 & 7 \\
\hline & Total & 50 & 50 & 100 \\
\hline
\end{tabular}

\section{Source: Primary Data}

The Table. 2 shows the age wise classification of the respondents. Out of the total 100 respondents 37 respondents belongs to the age category of below 30 that 28 of the respondents were from 
salaried people, which include 20 respondents belong to the age category of 51-60 that 13 of the respondents were from business people.

Table 3 Showing the Marital Status of the Respondents

\begin{tabular}{|l|l|l|l|l|}
\hline \multirow{2}{*}{$\begin{array}{l}\text { S. } \\
\text { No }\end{array}$} & Marital & \multicolumn{2}{|l|}{$\begin{array}{l}\text { Number } \\
\text { Investors }\end{array}$} & \multirow{2}{*}{ Total } \\
\cline { 3 - 4 } & & Salaried & Business & \\
\hline 1 & Married & 19 & 37 & 56 \\
\hline 2 & Unmarried & 28 & 10 & 38 \\
\hline 3 & Separated & 1 & 0 & 1 \\
\hline 4 & Widow & 2 & 3 & 5 \\
\hline & Total & 50 & 50 & 100 \\
\hline
\end{tabular}

Source: Primary Data

The Table. 3 shows that the marital status of the investors. Among the total investors, 56 investors belonged to married, which includes 19investors from salaried people and 37 from business class investors. Around 38 investors belonged to the unmarried, which includes 28 investors from salaried class and 10 investors from business class investors.

Table 4 Showing the Education of the Respondents

\begin{tabular}{|l|l|l|l|l|}
\hline $\begin{array}{l}\text { S. } \\
\text { No }\end{array}$ & Education & \multicolumn{2}{|l|}{$\begin{array}{l}\text { Number } \\
\text { Investors }\end{array}$} & of \\
\cline { 3 - 4 } & & Salaried & Business & \\
\hline 1 & Up to H. Sc & 5 & 13 & 18 \\
\hline 2 & U.G & 16 & 11 & 27 \\
\hline 3 & P.G & 23 & 14 & 37 \\
\hline 4 & IT/Polytechnic & 2 & 11 & 13 \\
\hline 5 & $\begin{array}{l}\text { Others } \\
\text { Specify }\end{array}$ & 4 & 1 & 5 \\
\hline & Total & 50 & 50 & 100 \\
\hline
\end{tabular}

\section{Source: Primary Data}

The Table.4 shows that the education classification of the investors. Among the total investors, 37 investors had completed their post graduation whereas it includes 23 investors from salaried people and 14 investors from business class investors. 27 investors had completed their under graduation, which includes 16 investors from salaried class and 11 investors from business class investors.

Table 5 Classifications of the Investors Based On Occupation

\begin{tabular}{|l|l|l|l|l|}
\hline $\begin{array}{l}\text { S. } \\
\text { No }\end{array}$ & $\begin{array}{l}\text { If } \\
\text { Salaried }\end{array}$ & Salaried & $\begin{array}{l}\text { If } \\
\text { Business }\end{array}$ & Business \\
\hline 1 & Government & 16 & Manufacture & 19 \\
\hline 2 & Public & 16 & Retail & 16 \\
\hline 3 & Private & 18 & Service & 15 \\
\hline & Total & 50 & & 50 \\
\hline
\end{tabular}

The Table.5 shows the classification of the investors. About 18 investors in private sector from salaried class, which includes 16 investors Public sector from salaried and 16 government sector investors from the salaried class investors. The remaining 19 investors manufacture from business class which includes 16 investors' retail investors from business and 15 investors Service sector investors from business people.

Table 6 Showing the Family Type of the Respondents

\begin{tabular}{|l|l|l|l|l|}
\hline S. & Type of & \multicolumn{2}{|l|}{ Number of Investors } & Total \\
\cline { 3 - 4 } family & Salaried & Business & \\
\hline 1 & $\begin{array}{l}\text { Nuclear } \\
\text { Family }\end{array}$ & 40 & 41 & 81 \\
\hline 2 & $\begin{array}{l}\text { Joint } \\
\text { Family }\end{array}$ & 10 & 9 & 19 \\
\hline & Total & 50 & 50 & 100 \\
\hline
\end{tabular}

\section{Source: Primary Data}

The Table. 6 shows the nature of family of the investors. About 81 investors live in nuclear family type, which includes 40 investors from salaried and 41 investors from the business class investors. The remaining 19 investors live in a joint family type which includes 10 investors from salaried and 9 investors' from business class people.

Table 7 Showing the Family Size of the Respondents

\begin{tabular}{|l|l|l|l|l|}
\hline S. & Family & \multicolumn{2}{|l|}{ Number of Investors } & \multirow{2}{*}{ Total } \\
\cline { 3 - 4 } No & size & Salaried & Business & \\
\hline 1 & Below 2 & 6 & 5 & 11 \\
\hline 2 & $3-4$ & 27 & 29 & 56 \\
\hline 3 & $5-6$ & 13 & 13 & 26 \\
\hline 4 & $7 \quad \&$ & 4 & 3 & 7 \\
\hline & $\begin{array}{l}\text { Above } \\
\text { Total }\end{array}$ & 50 & 50 & 100 \\
\hline
\end{tabular}

Source: Primary Data

The Table.7 shows the family size classification of the investors. Around 56 investors live with a 
family size of 3-4 members which includes 27 investors from salaried class investors and 29 investors from business people. 26 investors live a family size of 5-6 which includes 13 investors from salaried and 13investors from business people.

Table 8 Showing the Annual Income of the Respondents

\begin{tabular}{|c|c|c|c|c|}
\hline \multirow[t]{2}{*}{$\begin{array}{l}\text { S. } \\
\text { No }\end{array}$} & \multirow{2}{*}{$\begin{array}{l}\text { Family } \\
\text { annual } \\
\text { income }\end{array}$} & \multicolumn{2}{|c|}{$\begin{array}{l}\text { Number } \\
\text { Investors }\end{array}$} & \multirow[t]{2}{*}{ Total } \\
\hline & & Salaried & Business & \\
\hline 1 & Below 4 & 27 & 24 & 51 \\
\hline 2 & $4-8$ & 14 & 19 & 33 \\
\hline 3 & $8-12$ & 7 & 4 & 11 \\
\hline 4 & $\begin{array}{ll}12 & \& \\
\text { Above } & \\
\end{array}$ & 2 & 3 & 5 \\
\hline & Total & 50 & 50 & 100 \\
\hline
\end{tabular}

Source: Primary Data

The Table. 8 shows the family annual income classification of the investors. 51 have mentioned that they earn family annual income of Rs. below 4lakh which includes 27 investors from salaried people and 24 investors from business people. 33 investors have mentioned that they earn annual income of Rs.4-8lakh which includes 14 investors from salaried people and 19 investors from business people.

Table 9 Showing the Monthly Expenditure of the Respondents

\begin{tabular}{|l|l|l|l|l|}
\hline \multirow{2}{*}{$\begin{array}{l}\text { S. } \\
\text { No }\end{array}$} & $\begin{array}{l}\text { Monthly } \\
\text { expenditure }\end{array}$ & \multicolumn{2}{|l|}{$\begin{array}{l}\text { Number } \\
\text { Investors }\end{array}$} & Total \\
\cline { 3 - 4 } & & Salaried & Business & \\
\hline 1 & $\begin{array}{l}\text { Below } \\
10,000\end{array}$ & 14 & 15 & 29 \\
\hline 2 & $\begin{array}{l}10,000- \\
20,000\end{array}$ & 24 & 26 & 50 \\
\hline 3 & $\begin{array}{l}20,000- \\
30,000\end{array}$ & 8 & 5 & 13 \\
\hline 4 & $\begin{array}{l}\text { Above } \\
30,000\end{array}$ & 4 & 4 & 8 \\
\hline & Total & 50 & 50 & 100 \\
\hline
\end{tabular}

Source: Primary Data

The Table. 9 shows the monthly expenditure of the investors. 50 investors have mentioned that they expenditure of Rs.10, 000-20,000 which includes 24 investors from salaried people and 26 investors from business people. 29 investors have mentioned that they monthly expenditure of Rs. below 10,000 which includes 14 investors from salaried people and 15 investors from business people.

Table 10 Showing the Annual Savings of the Respondents

\begin{tabular}{|c|c|c|c|c|}
\hline \multirow[t]{2}{*}{$\begin{array}{l}\text { S. } \\
\text { No }\end{array}$} & \multirow[t]{2}{*}{$\begin{array}{l}\text { Annual } \\
\text { savings }\end{array}$} & \multicolumn{2}{|c|}{$\begin{array}{l}\text { Number } \\
\text { Investors }\end{array}$} & \multirow[t]{2}{*}{ Total } \\
\hline & & Salaried & Business & \\
\hline 1 & Below 1 & 27 & 31 & 58 \\
\hline 2 & $1-3$ & 18 & 13 & 31 \\
\hline 3 & $3-5$ & 4 & 3 & 7 \\
\hline 4 & $\begin{array}{ll}5 & \& \\
\text { Above }\end{array}$ & 1 & 3 & 4 \\
\hline & Total & 50 & 50 & 100 \\
\hline
\end{tabular}

Source: Primary Data

The Table.10 shows the annual savings of the investors. 58 investors have mentioned that they save annual sum of Rs. below 1lakh which includes 27 investors from salaried people and 31 investors from business people. 31 investors have mentioned that they save annual sum of Rs.13lakh which includes 18 investors from salaried people and 13 investors from business people.

Table no. 11 showing the annual investment of the respondents

\begin{tabular}{|l|l|l|l|l|}
\hline $\begin{array}{l}\text { S. } \\
\text { No }\end{array}$ & $\begin{array}{l}\text { Annual } \\
\text { investment }\end{array}$ & \multicolumn{2}{|l|}{$\begin{array}{l}\text { Number } \\
\text { Investors }\end{array}$} & \multirow{2}{*}{ Total } \\
\cline { 3 - 4 } & & Salaried & Business & \\
\hline 1 & Below 1 & 26 & 33 & 59 \\
\hline 2 & $1-2$ & 14 & 9 & 23 \\
\hline 3 & $2-3$ & 7 & 4 & 11 \\
\hline 4 & 3 \& Above & 3 & 4 & 7 \\
\hline & Total & 50 & 50 & 100 \\
\hline
\end{tabular}

Source: Primary Data

The Table.11 shows the annual investment of the investors. 59 investors have mentioned that they invest annual sum of Rs. below 1 which includes 26 investors from salaried people and 33 investors from business people. 23 investors have mentioned that they invest annual sum of Rs.12lakh which includes 14 investors from salaried people and 9 investors from business people.

Occupation and Frequency of Making Investment 
Null hypothesis: There is no significant association between the occupation of respondents and frequency of making investment.
Alternative hypothesis: There is significant association between the occupation of respondents and frequency of making investment.

Table no. 1: Occupation and frequency of making investment

\begin{tabular}{|c|c|c|c|c|c|}
\hline & \multicolumn{3}{|c|}{ Frequency of making investment } & \multirow[b]{2}{*}{ Total } \\
\hline & & $\begin{array}{l}\text { Every } \\
\text { month }\end{array}$ & $\begin{array}{l}\text { At the end of } \\
\text { every year }\end{array}$ & $\begin{array}{l}\text { Whenever surplus fund } \\
\text { is available }\end{array}$ & \\
\hline \multirow{2}{*}{$\begin{array}{l}\text { Occupation of } \\
\text { the respondents }\end{array}$} & Salaried & 29 & 7 & 14 & 50 \\
\hline & Business & 29 & 11 & 10 & 50 \\
\hline \multicolumn{2}{|l|}{ Total } & 58 & 18 & 24 & 100 \\
\hline \multicolumn{2}{|l|}{ Chi square } & \multicolumn{4}{|l|}{1.556} \\
\hline \multicolumn{2}{|l|}{ df } & \multicolumn{4}{|l|}{2} \\
\hline \multicolumn{2}{|c|}{ Asymp. Sig. (2-sided) } & \multicolumn{4}{|l|}{.459} \\
\hline
\end{tabular}

The $p$ value (0.459) is higher than 0.05 hence the null hypothesis is accepted. There is no significant association between the occupation of respondents and frequency of making investment. An individual makes investment on the basis of his earnings. These earnings are received by him in frequent intervals in the form of monthly salary in the case of salaried, profit in the case of business. So there exist an association between occupation and intervals in investing.
Family Annual Income and Frequency of Making Investment

Null hypothesis: There is no significant association between the family annual income of respondents and frequency of making investment.

Alternative hypothesis: There is significant association between the family annual income of respondents and frequency of making investment.

Table no. 2: Family annual income and frequency of making investment

\begin{tabular}{|c|c|c|c|c|c|}
\hline & \multicolumn{4}{|c|}{ Frequency of making investment } & \multirow[b]{2}{*}{ Total } \\
\hline & & $\begin{array}{l}\text { Every } \\
\text { month }\end{array}$ & $\begin{array}{l}\text { At the end } \\
\text { of } r \text { every } \\
\text { year }\end{array}$ & $\begin{array}{l}\text { Whenever surplus } \\
\text { fund is available }\end{array}$ & \\
\hline \multirow{4}{*}{$\begin{array}{lr}\begin{array}{l}\text { Your } \\
\text { average }\end{array} & \text { Family } \\
\text { annual income } \\
\text { (Rs.in Lakhs) }\end{array}$} & Below 4lakh & 30 & 10 & 11 & 51 \\
\hline & 4-8lakh & 19 & 5 & 9 & 33 \\
\hline & 8-12lakh & 7 & 1 & 3 & 11 \\
\hline & $\begin{array}{l}\text { 12lakh \& } \\
\text { above }\end{array}$ & 2 & 2 & 1 & 5 \\
\hline Total & & 58 & 18 & 24 & 100 \\
\hline Chi square & \multicolumn{5}{|l|}{2.753} \\
\hline $\mathrm{df}$ & \multicolumn{5}{|l|}{6} \\
\hline $\begin{array}{l}\text { Asymp. Sig. (2- } \\
\text { sided) }\end{array}$ & \multicolumn{5}{|l|}{.839} \\
\hline
\end{tabular}


The $\mathrm{p}$ value (0.839) is greater than 0.05 hence the null hypothesis is accepted. There is no significant association between the family annual income of respondents and frequency of making investment. Investors of same category of family annual income do not make investment in the same frequencies.
Individual Annual Income and Frequency of Making Investment

Null hypothesis: There is no significant association between the annual savings of respondents and frequency of making investment.

Alternative hypothesis: There is significant association between the annual savings of respondents and frequency of making investment.

Table no. 3: Individual annual income and frequency of making investment

\begin{tabular}{|c|c|c|c|c|c|c|}
\hline & \multicolumn{4}{|c|}{ What is the purpose behind investment } & \multirow[b]{2}{*}{ Total } \\
\hline & & $\begin{array}{l}\text { Wealth } \\
\text { creation }\end{array}$ & $\begin{array}{l}\text { Earn } \\
\text { returns }\end{array}$ & $\begin{array}{l}\text { Future } \\
\text { expenses }\end{array}$ & $\begin{array}{l}\text { Others } \\
\text { Specify } \\
\end{array}$ & \\
\hline \multirow{4}{*}{$\begin{array}{l}\text { Your annual } \\
\text { Savings (Rs.in } \\
\text { Lakhs) }\end{array}$} & Below 1 & 11 & 12 & 34 & 1 & 58 \\
\hline & $1-3$ & 8 & 9 & 14 & 0 & 31 \\
\hline & $3-5$ & 0 & 2 & 5 & 0 & 7 \\
\hline & $\begin{array}{l}5 \\
\text { above }\end{array}$ & 1 & 0 & 3 & 0 & 4 \\
\hline \multicolumn{2}{|l|}{ Total } & 20 & 23 & 56 & 1 & 100 \\
\hline \multicolumn{2}{|l|}{ Chi square } & \multicolumn{5}{|l|}{5.644} \\
\hline \multicolumn{2}{|l|}{ df } & \multicolumn{5}{|l|}{9} \\
\hline \multicolumn{2}{|c|}{ Asymp. Sig. (2-sided) } & \multicolumn{5}{|l|}{.775} \\
\hline
\end{tabular}

The $\mathrm{p}$ value $(0.775)$ is greater than 0.05 hence the null hypothesis is accepted. There is no significant association between the annual savings of respondents and purpose of investment. This shows that investor who belong to various scale of annual savings do not have similar frequencies in making investment.

Attitude-Towards Investments and Occupation of the Respondents

Table No.1.1 Descriptive Table on salaried class investors

\begin{tabular}{|l|l|l|l|l|}
\hline Salaried & & Mean & $\begin{array}{l}\text { Std. } \\
\text { Deviation }\end{array}$ & $\begin{array}{l}\text { Std. } \\
\text { Error }\end{array}$ \\
\hline Government & 16 & 1.7500 & .28255 & .07064 \\
\hline Public & 16 & 1.7917 & .23614 & .05903 \\
\hline Private & 18 & 1.7840 & .19608 & .04622 \\
\hline Total & 50 & 1.7756 & .23489 & .03322 \\
\hline
\end{tabular}

Table Summary of ANOVA between salaried class investors and investments attitude

\begin{tabular}{|l|l|l|l|l|l|}
\hline & $\begin{array}{l}\text { Sum of } \\
\text { Squares }\end{array}$ & Df & $\begin{array}{l}\text { Mean } \\
\text { Square }\end{array}$ & F & Sig. \\
\hline $\begin{array}{l}\text { Between } \\
\text { Groups }\end{array}$ & .016 & 2 & .008 & .139 & .871 \\
\hline $\begin{array}{l}\text { Within } \\
\text { Groups }\end{array}$ & 2.688 & 47 & .057 & & \\
\hline Total & 2.703 & 49 & & & \\
\hline
\end{tabular}

The calculated value (0.139) is less than the table value (3.23) at 5\% level of significance. Hence the null hypothesis is accepted. Hence we conclude that there is no significant difference between the attitude of government, public and private class of salaried investor towards investments. An investors needs may be short term or long term. He may give importance to a particular mode of investments according to his needs. So he feels essential to know about that specific avenue in 
depth. This may differ irrespective of their work group.

Table No.1.2 Descriptive Table on business class investors

\begin{tabular}{|l|l|l|l|l|}
\hline $\begin{array}{l}\text { Business } \\
\text { Class }\end{array}$ & $\mathbf{N}$ & Mean & $\begin{array}{l}\text { Std. } \\
\text { Deviation }\end{array}$ & $\begin{array}{l}\text { Std. } \\
\text { Error }\end{array}$ \\
\hline Manufacture & 19 & 2.3860 & .15873 & .03642 \\
\hline Retail & 16 & 2.3542 & .13589 & .03397 \\
\hline Service & 15 & 2.3185 & .19638 & .05071 \\
\hline Total & 50 & 2.3556 & .16342 & .02311 \\
\hline
\end{tabular}

Table Summary of ANOVA between Business class investors and investments attitude

\begin{tabular}{|l|l|l|l|l|l|}
\hline & $\begin{array}{l}\text { Sum of } \\
\text { Squares }\end{array}$ & Df & Square & F & Sig. \\
\hline $\begin{array}{l}\text { Between } \\
\text { Groups }\end{array}$ & .038 & 2 & .019 & .706 & .499 \\
\hline $\begin{array}{l}\text { Within } \\
\text { Groups }\end{array}$ & 1.270 & 47 & .027 & & \\
\hline Total & 1.309 & 49 & & & \\
\hline
\end{tabular}

The calculated value (0.706) is less than the table value (3.07) at 5\% level of significance. Hence the null hypothesis is accepted. Hence we conclude that there is no significant difference between the attitude of manufacture, retail and service class of business investor towards investments. An investors needs may be short term or long term. He may give importance to a particular mode of investments according to his needs. So he feels essential to know about that specific avenue in depth. This may differ irrespective of their work group.

Investment Pattern and Occupation of the Respondents

Table No.2.1 Descriptive Table on salaried class investors

\begin{tabular}{|l|l|l|l|l|}
\hline $\begin{array}{l}\text { Salaried } \\
\text { class }\end{array}$ & $\mathbf{N}$ & Mean & $\begin{array}{l}\text { Std. } \\
\text { Deviation }\end{array}$ & $\begin{array}{l}\text { Std. } \\
\text { Error }\end{array}$ \\
\hline Government & 16 & 2.1354 & .29950 & .07487 \\
\hline Public & 16 & 1.9063 & .42587 & .10647 \\
\hline
\end{tabular}

\begin{tabular}{|l|l|l|l|l|}
\hline Private & 18 & 1.9352 & .40880 & .09636 \\
\hline Total & 50 & 1.9900 & .38892 & .05500 \\
\hline
\end{tabular}

Table Summary of ANOVA between salaried class investors and investment pattern

\begin{tabular}{|l|l|l|l|l|l|}
\hline & $\begin{array}{l}\text { Sum of } \\
\text { Squares }\end{array}$ & $\begin{array}{l}\text { Mean } \\
\text { Square }\end{array}$ & F & Sig. \\
\hline $\begin{array}{l}\text { Between } \\
\text { Groups }\end{array}$ & .505 & 2 & .252 & 1.717 & .191 \\
\hline $\begin{array}{l}\text { Within } \\
\text { Groups }\end{array}$ & 6.907 & 47 & .147 & & \\
\hline Total & 7.412 & 49 & & & \\
\hline
\end{tabular}

The calculated value (1.717) is less than the table value (3.07) at 5\% level of significance. Hence the null hypothesis is accepted. Hence we conclude that there is no significant difference between the investment pattern of government, public and private class of salaried investors. An investor's pattern of investment is dependent on risk bearing capacity, Savings, time period of return, switching habit and knowledge about price fluctuations. There is commonality between the class of salaried investors and their investment pattern.

Table No.2.2 Descriptive Table on salaried class investors

\begin{tabular}{|l|l|l|l|l|}
\hline $\begin{array}{l}\text { Business } \\
\text { Class }\end{array}$ & $\mathbf{N}$ & Mean & $\begin{array}{l}\text { Std. } \\
\text { Deviation }\end{array}$ & $\begin{array}{l}\text { Std. } \\
\text { Error }\end{array}$ \\
\hline Manufacture & 19 & 2.1404 & .54224 & .12440 \\
\hline Retail & 16 & 2.2813 & .50815 & .12704 \\
\hline Service & 15 & 2.1000 & .60684 & .15669 \\
\hline Total & 50 & 2.1733 & .54602 & .07722 \\
\hline
\end{tabular}

Table Summary of ANOVA between business class investors and investment patterns

\begin{tabular}{|l|l|l|l|l|l|}
\hline & $\begin{array}{l}\text { Sum of } \\
\text { Squares }\end{array}$ & Df & $\begin{array}{l}\text { Mean } \\
\text { Square }\end{array}$ & F & Sig. \\
\hline $\begin{array}{l}\text { Between } \\
\text { Groups }\end{array}$ & .288 & 2 & .144 & .472 & .627 \\
\hline $\begin{array}{l}\text { Within } \\
\text { Groups }\end{array}$ & 14.321 & 47 & .305 & & \\
\hline Total & 14.609 & 49 & & & \\
\hline
\end{tabular}


The calculated value $(0.472)$ is less than the table value (3.07) at $5 \%$ level of significance. Hence the null hypothesis is accepted. Hence we conclude that there is no significant difference between the investment pattern of business, retail and service class of business investors. An investor's pattern of investment is dependent on risk bearing capacity, Savings, time period of return, switching habit and knowledge about price fluctuations.

\section{FINDINGS}

- The study reveals that out of the total 100 respondents 69 respondents were male and it includes 31 investors from salaried and 38 respondents from business people.

- The age of the respondents out of the total 100 respondents 37 respondents belongs to the age category of below 30 that 28 of the respondents were from salaried people, which include 20 respondents belong to the age category of 51-60 that 13 of the respondents were from business people.

- The marital status of the investors among the total investors, 56 investors belonged to married, which includes 19 investors from salaried people and 37 from business class investors.

- $\quad$ The level education among the total 37 investors had completed their post graduation whereas it includes 23 investors from salaried people and 14 investors from business class investors.

- It is clear about 40 investors belong to nuclear family from salaried and 41 investors from the business class investors.

- The family annual incomes of the 51 investors have mentioned that they earn family annual income of Rs. below 4lakh which includes 27 investors from salaried people and 24 investors from business people.

- The annual savings of 58 investors have mentioned that they save annual sum of Rs. below 1 which includes 27 investors from salaried people and 31 investors from business people.

- $\quad$ The annual investment of the investors 59 have mentioned that they invest annual sum of Rs. below 1 which includes 26 investors from salaried people and 33 investors from business people.

- The occupation of respondents and their frequency of making investment are no significantly associated i.e., the respondents' occupation influences their frequency of making investment not significantly.

- The calculated value $(0.839)$ is greater than table value (0.05) hence the null hypothesis is accepted. There is no significant association between the family annual income of respondents and frequency of making investment.

- The calculated value $(0.775)$ is greater than table value (0.05) hence the null hypothesis is accepted. There is no significant association between the annual savings of respondents and purpose of investment.

- The attitude towards investments calculated value $(0.139)$ is less than the table value (3.23) at 5\% level of significance. Hence the null hypothesis is accepted. Hence we conclude that there is no significant difference between the attitude of government, public and private class of salaried investor towards investments. The calculated value $(0.706)$ is less than the table value (3.07) at 5\% level of significance. Hence the null hypothesis is accepted. Hence we conclude that there is no significant difference between the attitude of manufacture, retail and service class of business investor towards investments.

- The investment pattern calculated value (1.717) is less than the table value (3.07) at $5 \%$ level of significance. Hence the null hypothesis is accepted. Hence we conclude that there is no significant difference between the investment pattern of government, public and private class of salaried investors. The calculated value $(0.472)$ is less than the table value (3.07) at $5 \%$ level of significance. Hence the null hypothesis is accepted. Hence we conclude 
that there is no significant difference between the investment pattern of business, retail and service class of business investors.

\section{CONCLUSION}

The studies especially relevant for the salaried and business people the inside of how and investment pattern get affect by the Socio-Economic variables helps the targeted respondents to make out the investment pattern. This study thus certainly improves the investment pattern and their choice to meet of their future investment. Similar studies with diverse samples will help in understanding the investment attitude of the targeted respondents in a better level.

The main reason has been observed to be the lack of awareness of investors about the concept and working of the investment pattern. Moreover, as far as the Socio-Economic variables are concerned, age, gender, income, education and occupation have been found influencing the attitude of investors towards investment significantly.

\section{BIBLIOGRAPHY}

1. Tamilkodi A.P.P. 1983. Small Savings Schemes in Tamil Nadu: A Trend Study (1970-80). Unpublished Thesis, University of Madras, Tamilnadu.

2. Jayaraman R. 1987. A study of small savings schemes in North Arcot District', 1976-86, Unpublished Thesis, University of Madras, Tamilnadu, India.
3. Mukhi M.D. 1989. NSCs. A saving grace', Business World, 6-19 December. Pp. 107120.

4. Somasundaram V.K. 1998. A Study on Savings and Investment Pattern of Salaried Class in Coimbatore district. Unpublished Thesis, Bharathiyar University, Coimbatore, Tamilnadu.

5. Guiso, L., Jappelli, T., \& Terlizzese, D. (1996). Income risk, borrowing Constraints, and portfolio choice. American Economic Review. 86(1), 158172.

6. Rajarajan.V (2003); Investors Demographics and risk bearing capacity; Finance India; 17(2), pp.565-576, June.

7. Sharma.B.C and Sharma Dinesh's (2004); An empirical study of stock investment behaviour in Jammu-An emerging market; Indian Journal of Finance and Research; Vol 14,Issue;1 and2.

8. Dr.V.L shobhana and J.Jayalakshmi. (2005) 'investor Awareness and Preference. A study" University of Madras, Tamilnadu.

9. Rajarajen Vanjeko (2010); Indian Investors' Investment Characteristics; Indian Institute of Finance, Vol.4, No.3\&4, December 2010, pp.1274-1294.

10. Love, D.A. (2010). The effects of marital status and children on savings and portfolio choice. The Review of Financial Studies, 23(1), 385-431. 